\title{
Botanical Features for Taxonomic Evidence of Erythroxylum monogynum Dried Leaf
}

\author{
Sabeena Hussain Syed, Ajay Gajanan Namdeo*
}

\section{Sabeena Hussain Syed, Ajay Gajanan Namdeo*}

Department of Pharmacognosy, Bharati Vidyapeeth Deemed University, Poona College of Pharmacy, Pune-411038, Maharashtra, INDIA.

\section{Correspondence}

\section{Dr. Ajay G Namdeo,}

Associate Professor, Department of Pharmacognosy Poona college of Pharmacy, Bharati Vidyapeeth Deemed University, Erandwane, Pune-411038, INDIA.

Phone no: 9881299129

E-mail: agnamdeo@gmail.com

\section{History}

- Submission Date: 22-02-17;

- Review completed: 05-03-17;

- Accepted Date: 23-03-17

DOI : 10.5530/pj.2017.3.67

Article Available online

http://www.phcogj.com/v9/i3

\section{Copyright}

(c) 2017 Phcog.Net. This is an openaccess article distributed under the terms of the Creative Commons Attribution 4.0 International license.

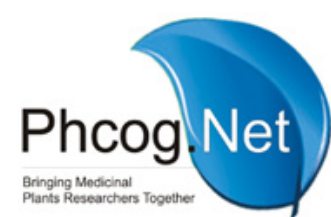

\begin{abstract}
Introduction: Erythroxylum monogynum belonging to family Erythroxylaceae is commonly found in southern parts of India. Traditionally, leaves of the plant possess high medicinal value and known for the treatment of diabetes, jaundice and to kill intestinal worms, which are scientifically reported. However, no elaborative pharmacognostic study of leaves has been performed yet. Objective: To pharmacognostically standardize the leaves by studying anatomical characters of transversal section and powdered leaves. Material and methods: Leaf samples were studied by macroscopy, microscopy, physicochemical and preliminary phytochemical analysis as recommended by WHO. Results: Externally the leaves are elliptic - lanceolate, alternate, base attenuate, apex obtuse and entire margin. Internally it shows the presence of paracytic stomata confined to lower epidermis, conjoint, collateral arc shaped vascular bundles encircled by sclerenchyma, lignified fibers and xylem vessels with spiral thickening. Powder microscopy revealed the presence of epidermis with papillae, phytochemical and physicochemical of powdered drug proved useful to differentiate the powdered drug material. Conclusion: The establishment of botanical features of leaf material will be useful in identification and standardization of Erythroxylum monogyum in obtaining quality formulations.

Key words: Microscopy, Paracytic stomata, Physicochemical, Phytochemical, Standardization, Vascular.
\end{abstract}

\section{INTRODUCTION}

Herbs represent major part in medicine for thousands of years and now herbal drugs play a significant role in health care management principally in developing countries. However, its acceptance is limited due to lack of standardization and stringent quality control. World Health Organization emphasized on standardization and quality control of herbal drugs, according to which standardization complies the physicochemical evaluation of crude drug such as ash values, moisture content, extractive values, crude fiber. The quality aspects of the drug majorly include macro and microscopic examination, qualitative and quantitative chemical evaluation and chromatographic fingerprinting. ${ }^{1}$

Correct identification and quality assurance of plant material is indispensable to ensure reproducible quality of herbal medicine, which will contribute to its safety and efficacy. ${ }^{2}$ In this study, pharmacognostic standardization of Erythroxylum monogynum (E.monogynum) include its morphological, anatomical and biochemical characteristics.

E.monogynum Roxb belongs to family Erythroxylaceae, commonly known as Bastard sandal or Red cedar. It is commonly found in southern parts of India. In folklore medicine, parts of the plant are claimed to have medicinal benefits. The infusion of bark and wood is used as stomachic, diaphoretic, stimulant, diuretic and also in mild cases of dyspepsia and continued fever. ${ }^{3}$ The leaves extract are mixed with yogurt to kill intestinal worms, where as leaf juice used for the treatment of jaundice., ${ }^{4,5}$ E.monogynum scientifically reported for its antibacterial activity, ${ }^{6}$ hepatoprotective and antidiabetic activity. ${ }^{8}$

The objective of the present study is to reveal the pharmacognostical, physicochemical and phytochemical aspects of leaves of E.monogynum which may help to develop quality, purity, authenticity of the drug and to distinguish from spurious and adulterated species

\section{MATERIAL AND METHODS}

Plant Material

The plant, E.monogynum was collected from Khammam District (Telangana) during flowering season. The plant was authenticated by Botanical Survey of India, Hyderabad. The leaves of the plant were dried, powdered and passed through 40 mesh sieve and stored in an airtight container for future use.

\section{Macroscopic analysis}

Fresh leaves of the plant were noted for the following macroscopical character: Size and shape, color, odor, taste, surfaces, base, apex, margin, venation, lamina and presence or absence of petiole.

\section{Microscopical analysis}

For microscopical studies, the leaves were cut and removed from the plant and thin hand sections were prepared. The sections were cleared with chloral hydrate solu- 
tion, stained with phloroglucinol-hydrochloric acid (1:1) and toludiene blue. Some hand sections were also examined in glycerine. ${ }^{9,10}$ The following characteristics were observed for their presence or absence: epidermal cells, type of stomata and trichomes. The transverse sections of the fresh leaves through the lamina and the midrib are also cleared, mounted and observed.

The powdered drug of the leaves was separately treated with solution of phloroglucinol-hydrochloric acid (1:1), acetic acid and iodine solution to identify the presence of lignified fibers, calcium oxalate crystals and starch grains ${ }^{9}$.

\section{Physico-chemical and Florescence analysis}

According to WHO guidelines parameters determined for the powdered leaves are Loss on drying, total ash, acid insoluble ash, water soluble ash. Petroleum Ether soluble extractive, Chloroform extractive value, alcohol soluble extractive ( $90 \%$ ethanol) and water-soluble extractive values were performed to find out the amount of ether, Chloroform, alcohol and water soluble constituents respectively. ${ }^{11}$ Powdered leaf material was analyzed by treating with various organic/inorganic reagents like $\mathrm{NaOH}, \mathrm{HCl}, \mathrm{HNO}_{3}$ and $\mathrm{H}_{2} \mathrm{SO}_{4}$ under visible light, short ultra-violet light $(254 \mathrm{~nm})$ and long ultra-violet light $(366 \mathrm{~nm}) .^{12}$

\section{Preliminary phytochemical analysis}

The air-dried leaves of E.monogynum were made into coarse powder. The powdered material was extracted by maceration technique using methanol as solvent for overnight. The obtained extract was filtered, evaporated to dryness and subjected to qualitative chemical tests according to standard procedures. ${ }^{13}$

\section{RESULTS}

\section{Macroscopic characteristics}

Macroscopically, E.monogynum has pinnately compound leaves, alternate in arrangement. The leaflets were 7-8 pairs and shaped obovate or oblanceolate, base attenuate or cuneate, apex obtuse, margin entire, secondary veins are pinnately arranged. The leaf size is $2-4 \mathrm{~cm}$ long, 0.8 to $1 \mathrm{~cm}$ wide and petiolate where petiole is $0.3-0.6 \mathrm{~cm}$ in length. Fresh leaves are green, odorless and have bitter taste (Figure 1).

\section{Microscopical characteristics}

The transverse section of a leaf of E.monogynum shows dorsi ventral characters. The important characteristics in the midrib regions are as follows:

The midrib slightly protrudes convexly at the dorsal side and strongly projects at the ventral side. The epidermis is composed of single layer of barrel shaped cells. Adaxial epidermis is without stomata but abaxial side consists of paracytic stomata and rounded papillae. Collenchyma consists of 2-3 layers of cells which are present below both upper and lower epidermis. Intercellular spaces are present between collenchyma cells. It is followed by cortex composed of $3-4$ layered oval - circular parenchymatous cells. Conjoint, collateral, arc shaped vascular bundles are present which are encircled by lignified sclerenchyma fibres. Xylem vessels are lignified, composed of spiral thickening (Figure 2).

T. S. of laminar region shows both upper and lower epidermis. Palisade cells are compact, elongated and confined to lower portion of upper epidermis which is followed by loosely arranged spongy parenchymatous cells. Papillae-elongated cells are present below lower epidermis (Figure 3).

\section{Powder Characteristics}

Powder is dull greenish in color, with bitter taste and faint odor. The leaf powder showed fragments of epidermis with paracytic stomata, epidermal

\section{Table 1: Physicochemical parameters of E.monogynum leaves}

\begin{tabular}{cc}
\hline Parameters & $(\% \mathrm{w} / \mathrm{w})$ \\
\hline Loss on drying & $6.20 \%$ \\
Total ash & $8.03 \%$ \\
Acid insoluble ash & $5.50 \%$ \\
Water soluble ash & $2.51 \%$ \\
Pet ether soluble extractive & $5.12 \%$ \\
Chloroform & $12.15 \%$ \\
Alcohol soluble extractive & $18.11 \%$ \\
Water soluble extractive & $12.04 \%$ \\
\hline
\end{tabular}

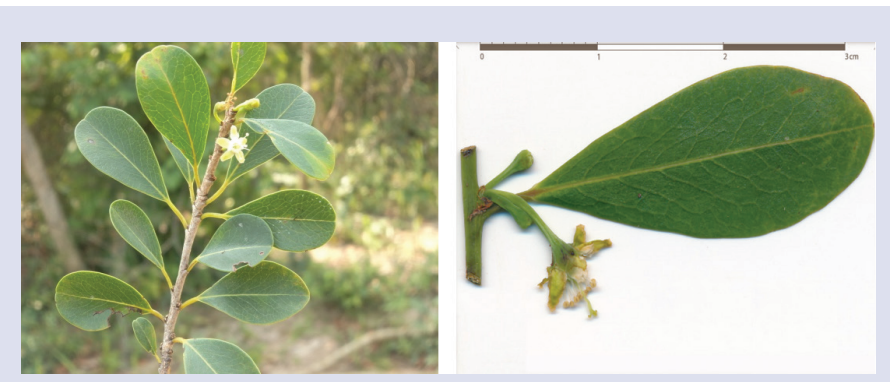

Figure 1: Macroscopic characters of leaves of E. monogynum

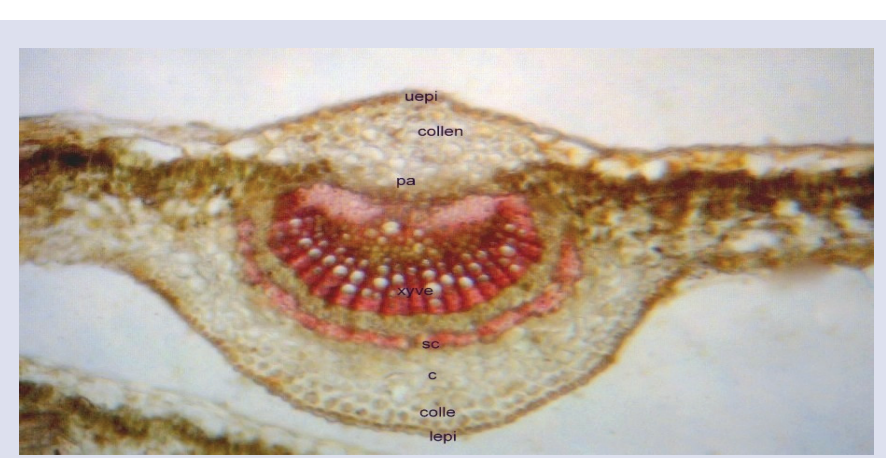

Figure 2: Microscopical characters of E.monogynum leaf midrib (T.S) Uepi: upper epidermis; Collen: Collenchyma; Pa: Parenchyma; Xyve: Xylem Vessels;Sc: Sclerenchyma; C: Cortex; Colle: Collenchyma; lepi: lower epidermis

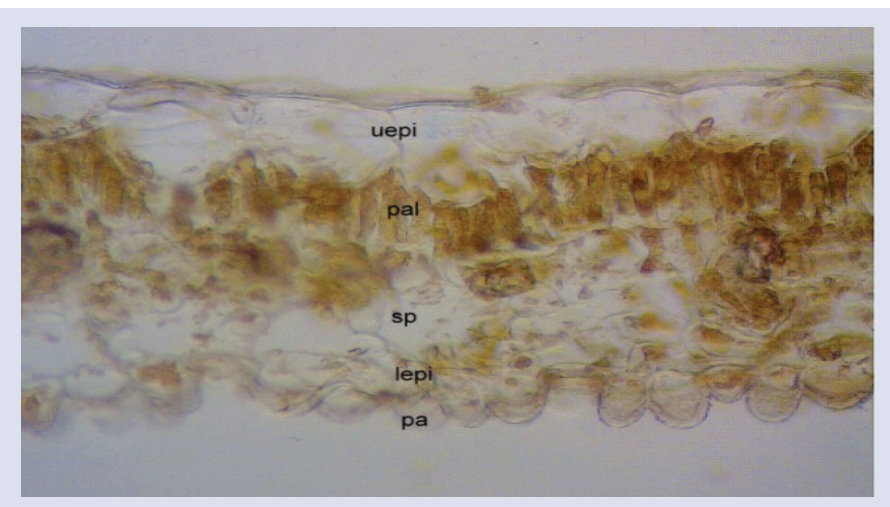

Figure 3: T.S of laminar portion of E.monogynum Uepi: upper epidermis; Pal: palisade parenchyma; Sp: spongy parenchyma; Lepi: lower epidermis; Pa: papillae 


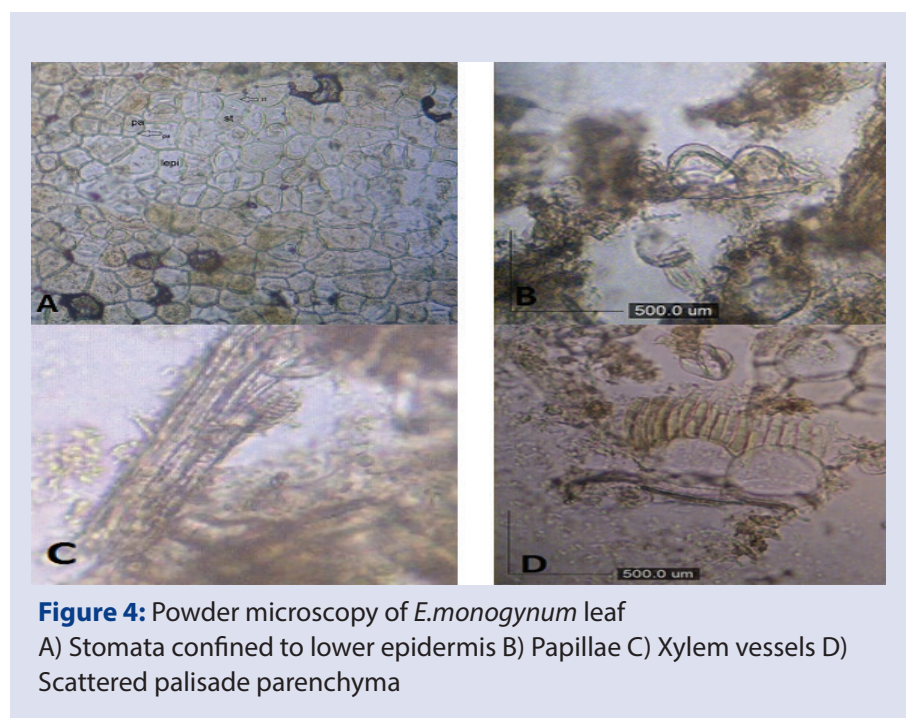

Table 2: Fluorescence analysis of powdered leaves of E.monogynum

\begin{tabular}{cccc}
\hline \multirow{2}{*}{ Reagents } & \multicolumn{2}{c}{ Color observed under day light } & \multicolumn{2}{c}{ Color observed under ultraviolet light } \\
\cline { 3 - 4 } & & Short (254nm) & Long (365) \\
\hline Powder as such & Dark green & Green & Grey Green \\
$1 \mathrm{~N} \mathrm{NaOH}$ in Methanol & Pale green & Green & Light blue \\
$1 \mathrm{~N} \mathrm{NaOH}$ in water & Citrine green & Green & Light blue \\
$1 \mathrm{~N} \mathrm{HCl}$ & Greenish yellow & Green & Brownish green \\
$50 \% \mathrm{HNO}_{3}$ & Dark brown & Brown & Reddish brown \\
$50 \% \mathrm{H}_{2} \mathrm{SO}_{4}$ & Brownish green & Brown & Reddish brown \\
\hline
\end{tabular}

Table 3: Preliminary phytochemical analysis of E.monogynum leaf extract

\begin{tabular}{|c|c|c|c|c|c|}
\hline $\begin{array}{l}\text { Chemical } \\
\text { constituents }\end{array}$ & Chemical tests & $\begin{array}{l}\text { Petroleum } \\
\text { ether extract }\end{array}$ & $\begin{array}{l}\text { Chloroform } \\
\text { extract }\end{array}$ & $\begin{array}{c}\text { Methanolic } \\
\text { extract }\end{array}$ & $\begin{array}{c}\text { Aqueous } \\
\text { extract }\end{array}$ \\
\hline \multirow[t]{3}{*}{ Carbohydrates } & Molisch's test & - & + & + & + \\
\hline & Fehling's test & - & + & + & + \\
\hline & Benedict's test & - & - & + & + \\
\hline \multirow[t]{3}{*}{ Alkaloids } & Dragendroff's test & + & - & - & - \\
\hline & Mayer's test & + & - & - & - \\
\hline & Wagner's test & + & - & - & - \\
\hline Saponin glycosides & Foam test & - & + & + & + \\
\hline \multirow{2}{*}{$\begin{array}{c}\text { Triterpenoidal } \\
\text { glycosides }\end{array}$} & Libermann burchard test & + & + & + & - \\
\hline & Salkowski tet & + & + & - & - \\
\hline \multirow[t]{2}{*}{ Flavonoids } & Shinoda test & - & - & + & + \\
\hline & Lead acetate test & - & - & + & + \\
\hline \multirow[t]{3}{*}{ Phenols } & Ferric chloride test & - & - & + & + \\
\hline & Bromine water test & - & - & + & + \\
\hline & Lead acetate test & - & - & + & + \\
\hline
\end{tabular}

+: Present, -:Absent

cells with papillae in surface view. Xylem consisting of vessels with spiral thickening was observed. Fragments of sclereids and scattered palisade cells of laminar portion are the characteristic features of powder microscopy for the leaf of E.monogynum (Figure 4).

\section{Physicochemical constants}

Physicochemical analysis of leaf viz. loss on drying, ash value and extractive value are presented in Table 1 . The fluorescence analysis of leaf powder observed under day light, short ultra-violet light $(254 \mathrm{~nm})$ and long ultra-violet light $(366 \mathrm{~nm})$ mentioned in Table 2.

\section{Preliminary phytochemical analysis}

Qualitative analysis of leaves of E.monogynum petroleum extract, chloroform extract, methanolic extract and aqueous extract showed the presence of alkaloids, flavonoids, saponins, phenols, terpenoids and alkaloids in respective tests which are mentioned in Table 3 


\section{DISCUSSION}

Ethnomedically, the leaves of E.monogynum were used by local people in the treatment of some ailments without standardization. Pharmacognostic standardization plays an important role in identification, authentification and determining the level of adulteration, which help in establishing quality control of crude drugs. ${ }^{14}$ In this study, pharmacognostic standards for leaves of E.monogynum are carried out for the first time.

The microscopical characters of the leaf which serves as diagnostic parameters, revealed the presence of conjoint, collateral, arc shaped vascular bundles containing spiral shaped xylem vessels encircled by lignified sclerenchyma fibers. The palisade parenchyma confined to lower portion of upper epidermis. Physicochemical analysis of the drug could be useful for identification of adulterants and also in compilation of a suitable monograph. Ash values are validity parameters to judge the identity or purity of the crude drug. Extractive value mainly used to determine the exhausted or adulterated drugs along with estimation of specific components soluble in particular solvents. ${ }^{15}$ In this study higher extractive value of methanol than water indicates more methanolic soluble components. The fluorescence analysis of drug extract helps to identify the drug with specific fluorescent colors and to resolve doubtful specimens.

Phytochemical evaluation is to determine the class of compounds present in the plant parts, which also suggests possibility of any potent pharmacological active constituents in determination of biological assays.ss ${ }^{16}$

\section{CONCLUSION}

The present study established pharmacognostic standardization of leaves of E.monogynum, which can serve as an important source to determine the quality and purity of the drug. This work also could be useful in compilation of a suitable monograph and further establishing standard data in pharmaceutical preparation from leaves of E.monogynum.

\section{ACKNOWLEDGEMENT}

The authors acknowledge the grants received from University Grants Commission (UGC) for this project under Maulana Azad National Fellowship (MANF) Scheme. F1-17.1/2010/MANF-MUS-AND-4007/ (SA-III/Website).

\section{CONFLICT OF INTEREST}

None

\section{ABBREVIATION USED}

TS: Transverse section; E. monogynum: Erythroxylum monogynum; WHO: World Health Organization;

\section{REFERENCES}

1. WHO. Guidelines for the Assessment of Herbal Medicines. WHO Technical Report Series. Geneva: WHO; 1996. p. 863.

2. Kadam PV, Yadav KN, Narappanawar NS, Shivatare RS, Bhusnar HU, Patil MJ. Development of Quality Standards of Terminalia catappa Leaves. Pharmacognosy J 2011;3:19-24. https://doi.org/10.5530/pj.2011.26.4

3. Kirtikar KR, Basu BD. Indian Medicinal Plant. 2nd ed, Vol I. Dehradun: International Book Distributors; 1987. p.415

4. Parrotta JA. Healing plants of peninsular India. CAB International; 2001. p. 279-80.

5. Rajendran A, Rama Rao N, and Henry AN. Hepatic stimulant plants of Andhra Pradesh. J. Econ Tax Bot (Additional Series). 1996:12:221-3.

6. Srinivasan D, Sangeetha N, Suresh T, Lakshmana P. Antimicrobial activity of certain Indian medicinal plants used in folklore medicine. J.Ethnopharmacol $2001 ; 74(3): 217-20$. https://doi.org/10.1016/S0378-8741(00)00345-7.

7. Sabeena SH, Namdeo AG. Hepatoprotective effects of leaves of Erythroxylum monogynum Roxb. on paracetamol induced toxicity. Asian Pac J Trop Biomed 2013;3(11):877-81. https://doi.org/10.1016/S2221-1691(13)60172-0.

8. Rupesh SK, Ravindra KR, Jayveera KN. Evaluation of Anti-diabetic potential of Erythroxylon monogynum in streptozotocin induced diabetic rats. Int J Adv Res 2014;2:550-60.

9. Khandelwal KR. Practical pharmacognosy-technique and experiments, 19th ed. Nirali Prakashan, Pune. 2008; p.149-160

10. O'Brien TP, Feder N, Mc Cull ME. Polychromatic staining of plant cell walls by toludiene blue-O.Protoplasma 1964;59(2):364-73. https://doi.org/10.1007/ BF01248568.

11. WHO/PHARM/92.559/rev.1. Quality control methods for medicinal plant materials. Geneva: Organization Mondiale De LaSante. 1992; p.22-34.

12. Pratt RJ, Chase CR. Fluorescence of powdered vegetable drugs with particular reference to development of a system of identification. J Am Pharm Assoc 1949;38(6):324-33. https://doi.org/10.1002/jps.3030380612

13. Kokate CK. Practical Pharmacognosy. 4th ed. Vallabh Prakashan, New Delhi; 2010. p.17-26

14. Alam F and Sagib Q.N. Pharmacognostic study and Development of quality control parameters for fruit, bark and leaf of Zanthoxylum armatum (Rutaceae). Anc Sci Life 2015 34(3):147-155. https://doi.org/10.4103/0257-7941.157159; PMid:26120229 PMCid:PMC4458905

15. Chumbhale DS, Upasani CD. Pharmacognostic standardization of stems of Thespesia lampas (Cav.) Dalz\&Gibs. Asian Pac J Trop Biomed 2012;2(5):357-63. https://doi.org/10.1016/S2221-1691(12)60056-2.

16. Singh S., Semwal B.C and Neeli G.S. Microscopic and Physicochemical Evaluation of leaves of Sphaeranthus indicus Linn. Pharmacognosy J. 2017 9(1):21-6.

\section{GRAPHICAL ABSTRACT}

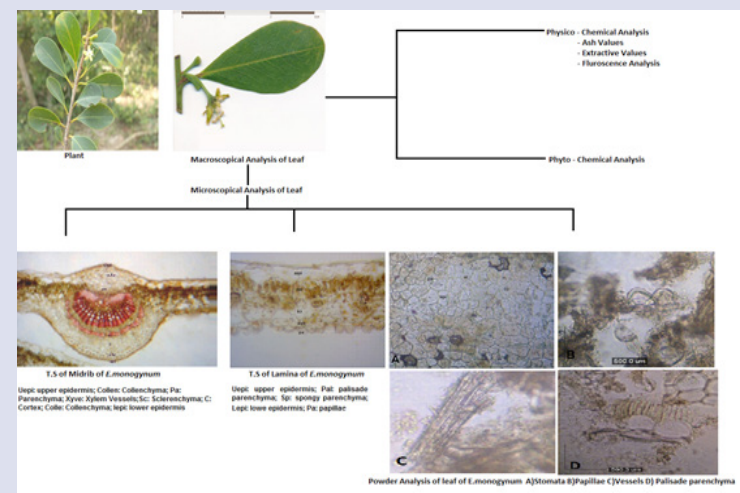

\section{SUMMARY}

- The plant Erythroxylum monogynum is claimed to have medicinal benefits in folklore medicine.

- Microscopical characters of leaves revealed the presence of paracytic stomata, collenchyma in the midrib region and presence of Conjoint, collateral, arc shaped vascular bundles encircled by lignified sclerenchyma fibres.

- $\quad$ Phytochemical analysis showed the presence of alkaloids, flavonoids, saponins, terpenoids and phenols.

- Pharmacognostical evaluation of leaves of Erythroxylum monogynum could be useful in standardization and in compilation of suitable monograph. 


\section{ABOUT AUTHORS}

Dr. Ajay G Namdeo: He is presently working as Associate Professor and HOD in the Dept of Pharmacognosy, Poona College of Pharmacy, Bharati Vidyapeeth Deemed University, Pune. He has nine years of industrial and seventeen years of academic experience. He has published 45 papers in International and National journals and presented 30 research papers in International and National conferences.

Sabeena Hussain Syed: She is presently working as a Research Scholar in Department of Pharmacognosy, Poona College of Pharmacy, Bharati Vidyapeeth Deemed University, Pune.

Cite this article: Syed SH, Namdeo AG. Botanical Features for Taxonomic Evidence of Erythroxylum monogynum Dried Leaf. Pharmacogn J. 2017;9(3):395-9. 